УДК 37.026 .6

DOI:

Неля Сірант, кандидат педагогічних наук, доиент кафедри початкової та дошкільної освіти Львівського національного університету імені Івана Франка

Ольга Мисик, студентка V курсу факультету педагогічної освіти Львівського національного університету імені Івана Франка

\title{
АКТУАЛЬНІСТЬ ЗАСТОСУВАННЯ ДІЛОВОЇ ГРИ У ЗАКЛАДАХ ПОЧАТКОВОЇ ОСВІТИ
}

Стаття містить аналіз можливих способів використання ділової гри на уроках для вивчення різних галузей знань здобувачами початкової освіти. Автори провели аналіз ключових умов проведення ділової гри, котрі сприяють ефективному засвоєнню знань $і$ забезпечують здобувачам початкової освіти оволодіння ключовими компетентностями, які передбачені освітньою типовою програмою. Результативність проведеноі гри залежить від методики ї̈ організаиії та проведення. Звернено увагу на механізми підготовки та проведення ефективної ділової гри. Розглянуто етапи організачії навчальної діяльності здобувачів початкової освіти під час реалізації иього ігрового методу. За результатами анкетування виявлено, щя не всі учителі початкових класів практикують застосування ігрового методу “Ділова гра", а лише меншість усвідомлюють позитивний результат його використання у закладах початкової освіти.

Ключові слова: ключові компетенції; ігровий метод; ділова гра; методи навчання; методика проведення гри.

Jim. 10.

Nelya Sirant, Ph.D.(Pedagogy), Associate Professor of the Primary and Preschool Education Department of Ivan Franko National University of Lviv Olga Mysyk, 5th year student, Faculty of Pedagogical Education Ivan Franko National University of Lviv

\section{RELEVANCE OF APPLICATION OF BUSINESS GAME IN PRIMARY EDUCATION INSTITUTIONS}

The article contains an analysis of possible ways to use the business game in lessons to study different areas of knowledge by primary school students. The authors analyzed the key conditions of the business game that promote the effective assimilation of knowledge and provide primary school students with the mastering key competencies provided by the standard educational program. The effectiveness of the game depends on the method of its organization and conduct. Attention is paid to the mechanisms of preparation and conduct of an effective business game. The stages of organization of educational activity of primary school students during the implementation of this game method are considered. According to the results of the survey, not all primary school teachers use the game method "Business Game", and only a minority are aware of the positive results of using this method in primary schools.

Today, the business game is becoming an institution of public relations for any individual. During the business game the child learns large ranges of human feelings and relationships, learns to recognize good and evil. According to the business game, the ability to emphasize one's inclinations, to determine how they are accepted by others is created, and there is a demand to build personal behavior taking into account the feasible reaction of the opposite.

Creating an enterprising, thoughtful, independent individual will be successful when the teacher takes care of it from the main lesson. The main one of the most promising areas of education of avid applicants, equipping them with the necessary skills and abilities is the introduction of active forms and methods of teaching, among which the defining place belongs to educational business games.

In childhood, business play is the main type of child's work. Without play, children's lives become uninteresting, boring. In the game, children and teenagers test their own strength and agility, they have the will to fantasize, discover secrets and strive for something beautiful. Under skillful guidance, the game becomes an indispensable assistant teacher.

Arranging the play activities of children and adults, it is important to remember that it is not in the form of the game or its game result, but in what relationship and with whom the player enters it, what qualities he acquires, what he learns, what he gets to know, what discovers in itself how it expresses itself, affects the world around it.

But in order to successfully conduct business games, it is necessary to follow the mandatory rules that make the game space safe. These include clearly defined deadlines that should not be violated, a well-defined day of the 
week, stability and regularity. It is also very important to follow the agreements that were accepted by all children during the business game.

Thus built a reliable play leisure in turn becomes a "figurative educational leisure", where the child will improve and overcome the difficulties between fantasy and reality.

Keywords: key competencies; game method; business game; teaching methods; game methods.

П остановка проблеми. На сучасному етапі розвитку людства ми маємо можливість спостерігати стрімкий розвиток і видозміну системи освіти, зокрема це стосується загальної початкової освіти. Сучасна освіта має на меті не лише зробити освітній процес максимально ефективним та результативним, а ще й спрямовувати його під потреби й особливості здобувачів початкової освіти. Відповідно до вимог Державного стандарту початкової освіти і Нової української школи, маємо певну низку компетентностей, які вчителі початкової освіти повинні розвинути у здобувачів [3]. Головне завдання педагогів полягає у тому, щоб вміло реалізувати передбачені вимоги, знайти і застосувати сучасний підхід до організації освітнього процесу.

Проте сучасне покоління здобувачів початкової освіти вимагає сучасних методів навчання. Унаслідок цього маємо справу із таким явищем, як гейміфікація (ігрофікація) у навчальному процесі. На сучасному етапі гейміфікації актуальною проблемою $€$ недосконале знання та неповне вміння вдало і повною мірою застосовувати всі форми та методи ігрової діяльності на уроках у закладі початкової освіти $[9,156]$.

Здобувачі початкової освіти не проявляють активного зацікавлення у процесі навчання, до якого звикло попереднє покоління. Тому сучасному вчителеві важливо вміти підібрати такі форми, засоби та методи навчання, які забезпечать не лише набуття необхідних знань, умінь та навичок, але й зацікавлять і мотивують здобувачів до активної участі у освітньому процесі.

Опираючись на аналіз численних наукових праць психологів та педагогів, з'ясовано, що одним 3 найефективніших у закладі початкової освіти є метод гри. Ділова гра здатна зробити перехід до навчальної діяльності плавним і більш комфортним для дітей. Вона підвищує емоційну складову освітнього процесу і передусім кожного уроку, здатна істотно підвищити ефективність засвоєння знань здобувачами, а також їню працездатність $[7,43]$. Зокрема, опираючись на Нову українську школу бачимо, що одним із головних умінь у розвитку здобувача освіти $\epsilon$ критичне мислення. I саме ділова гра є тим методом який допоможе якнайкраще реалізувати й розвинути цю життєво-необхідну та освітньонаскрізну компетентність.

Ми провели онлайн опитування, у якому взяли участь 20 учителів початкової освіти СЗШ № 54 Львова. Аналіз отриманих результатів засвідчив, що лише 6 учасників використовують ділову гру на своїх уроках. На запитання: чи варто використовувати такий ігровий метод у процесі вивчення у закладі початкової освіти, усі респонденти відповіли ствердно. Це говорить про готовність вчителів до використання нових для них ігрових методів. 3 огляду на це вважаємо за необхідне здійснити аналіз можливих способів використання ділової гри у процесі навчання здобувачів початкової освіти.

Аналіз основних досліджень і публікацій. Вивченню теорії гри загалом наукові роботи присвятили знаніпедагоги:Г.Ващенко, Я. Коменський, С. Лісова, А. Макаренко, С. Русова, М. Тименко тапсихологи Б. Ананьєва, Л. Виготський, О. Киричука та С. Рубінштейн. Вони визначили функції гри, їі види, класифікації ділових ігор, їх типи та пояснили, задля чого і за яких умов використовувати рольову гру, а також наголошували, що освітній процес має якісний результат за умови активної діяльності.

Проблеми застосування ділової гри у закладі освіти студіювали А. Вербицький, М. Касьяненко, М. Крюков та інші, а психолого-педагогічні аспекти використання ділових ігор у навчальному і виховному процесах, Н. Анікєєва, О. Булигіна, Д. Ельконін, Н. Кудикіна, М. Кларін, Т. МарчійДмитраш, О. Мицик, В. Паламарчук, О. Савченко та ін.

Мета статті-висвітлити теоретичну сторону сутності методу “Ділова гра” та їі застосування на уроках у Новій українській школі.

Виклад основного матеріалу. Ділова гра метод пошуку рішень в умовній проблемній ситуації, форма відтворення предметного і соціального змісту професійної діяльності, моделювання систем відношень, характерних для певного виду практики [8, 2-5].

У контексті знань та механізму процесу виховання Л. Артемова вважає що "психологічним об'єктом виховання є смислова сфера особистості особистісні смисли та особистісні смислові установки, що виявляються у поведінці особистості" [1,383]. Тому ділова гра - це метод який, власне, має усі підстави стати інструментом у педагогічній діяльності для корекції смислів та смислових установок особистості. 
Л. Артемова вважає: “Гра - потреба зростаючої дитини, свобода саморозкриття, головна сфера спілкування дітей” $[1,3]$.

Використання ділової гри на уроках Нової української школи $є$ фундаментом для формування у здобувачів початкової освіти позитивної мотивації до навчання, тобто природно продукує бажання дитини до пізнання нового та роботи над собою. Цей метод дає можливість працювати над інтелектуальною складовою, бачити дитину у різних ситуаціях, зрозуміти іiі спосіб мислення, сильні та слабкі сторони.

Проведення ділової гри - це розгортання особливої (ігрової) діяльності учасників на моделі імітаційної, що відтворює умови й динаміку виробництва. Залежно від того, який тип людської практики відтворюється у грі й яка мета в учасників, розрізняються ігри ділові, навчальні, дослідні, управлінські, атестаційні. Мотивація, інтерес та емоційний статус учасників ділової гри зумовлюється широкими можливостями для цілепокладання і досягнення цілей, для діалогічного спілкування на матеріалі проблемного змісту ділової гри [5, 3-9].

Ділові ігри насправді не є інновацією. Учений М. Бирштейн у 1932 р. створив першу ділову гру. Але активно застосовувати цей вид дидактичної гри в освітньому процесі почали у середині 1950 p. у США на базі Американської асоціації керування.

Досить поширеним явищем сьогодення в освіті $\epsilon$ використання ділової гри у навчальному процесі.

Фактично, ділова гра має дві складові: формальну (мета, спосіб оцінювання результату, формальні правила гри, мета конкретної ситуації) та неформальну (учасники, неформальні правила, коло гри).

Періоди побудови ділової гри:

1. Підготовка - розробка й організація гри (складання сценарію і плану ділової гри, підготовка її загального опису, матеріального забезпечення, постановка проблеми, розподіл ролей, формування груп, консультації, визначення змісту інструктажу і його проведення).

2. Проведення - групова робота над завданням і міжгрупова дискусія (опрацювання інформації, тренінг, мозковий штурм, презентація і захист результатів).

3. Аналіз і узагальнення (вихід із гри, рефлексія, аналіз, оцінювання роботи, висновки й узагальнення, рекомендації) [2, 2-14]. Якщо дотримуватись відповідної структури при організації ділової гри, вчитель побачить результат та рівень учнівської навченості.

А головне - реалізувати основну мету навчання, тобто формування ключових компетентностей:

1. Спілкування державною мовою (здобувачі вчаться формулювати свої думки, аргументувати ïx та вдало, переконливо висловлювати, швидко підбирати правильну ділову гру у непередбачуваних ситуаціях, збільшують словниковий запас).

2. Спілкування іноземними мовами (за умов використання ділової гри на уроках іноземної мови, поповнюють словниковий запас, вчаться пояснювати речі чи проблеми різносторонньо, долаючи мовні бар'єри).

3. Математична компетентність (розвиток логічного мислення, встановлення причинновонаслідкових зв'язків, визначення раціонального шляху розв'язання проблеми).

4. Основні компетентності у природничих науках (засвоюють базові знання з природничих наук, можуть вступати в бесіди та бути нарівні зі спеціалістами, здатність самостійно робити висновки з певних питань).

5. Інформаційно-цифрова компетентність (формують навички роботи з цифровими даними, також вміння їх розуміти та розшифровувати, використовують числові та цифрові дані відповідно до своєї мети).

6. Уміння вчитися протягом життя (усвідомлюють важливість процесу навчання упродовж життя, оскільки прослідковуються зміни у суспільстві, які вимагають нових навичок; вчаться самостійно знаходити інформацію та здобувати нові знання).

7. Ініціативність і підприємливість (не бояться висловлювати свою думку, проявляють ініціативу стосовно питань та подій, які їх зацікавлюють, здатні приймати правильні та корисні рішення, виховувати в собі риси підприємливої людини).

8. Суспільна та громадянська компетентність (відчувають свою значущість та важливість обгрунтованого висловлення особистої думки, усвідомлюють власну роль у суспільстві, важливість свого впливу на глобальні події, вчаться поводитись у суспільстві та співіснувати з іншими людьми).

9. Обізнаність та самовираження у сфері культури (збагачують знання, розширюють свій світогляд, вчаться розуміти твори мистецтва та культуру загалом).

10.Екологічна грамотність і здорове життя (у процесі гри учні діляться думками та роздумами, аргументують їх, роблять спільні висновки, переконують одне одного, спільно шукають позитивні та негативні риси) [6, 14-17].

Як уважає I. Джелялова, визначальними домовленостями результативності застосування ділової гри є органічне залучення здобувачів до 
ходу навчання, наявність стопроцентних ігрових деталей, неухильні правила, котрі ніяк неможливо порушувати; захоплюючі назви, емоційність учителя в часі проведення гри, використання лічилок [4, 52]. Ефективність ділової гри залежить від методики їі проведення та організації. Бо значимість ігрового методу полягає у тому, що це добре знайома, цікава та улюблена дітьми діяльність. У ході ігрового моменту набагато простіше долати труднощі, страхи тощо, бо атмосфера навчання стає вільною і невимушеною. У силу цього психологічні та психічні реакції не блокуються, і вчитель бачить здобувача, як розгорнуту книгу. Таке вільне відчуття у процесі навчання спонукає дітям не боятися проявити ініціативу, вони розуміють своє право на помилку i не бояться помилятись, ділова гра допомагає набувати нового досвіду, відчути свою індивідуальність та важливість, вчить знаходити спільну мову, аргументовано доводити свою думку. Навчання у такому процесі допомагає зберегти самодостатність кожного здобувача початкової освіти, розвиває творчість та впевненість у собі. А найголовніше, що ділова гра має кінцевий результат і це чудово для здобувачів початкової освіти, оскільки працювати на перспективу вони ще не здатні з огляду на вікові особливості, а видимість результату тут і зараз це додатковий стимул працювати далі $[10,368]$.

Висновки. Тож як підсумок можемо стверджувати, що використання ділової гри на уроках Нової української школи має безліч плюсів. Якщо застосовувати його грамотно та систематично можна забезпечити здорове інтелектуальне, емоційне та психологічне піднесення у здобувачів початкової освіти, а основне - створити ефективний і продуктивний освітній процес.

\section{ЛІТЕРАТУРА}

1. Артемова Л.В. Вчися граючись. Київ : Томіріс, $1990.170 \mathrm{c}$.

2. Булигіна О. Ігрові технології: шляхи забезпечення умов для інтелектуального, соціального, морального розвитку молодших школярів. Початкове навчання та виховання. 2009. № 19-21. С. 2-14.

3. Державний стандарт початкової освіти (Міністерство освіти і науки України). URL: https:// zakon.rada.gov.ua/laws/show/688-2019-\%D0\%BF\#Text (дата звернення 24.07.2021).

4. Джелялова І. Гра як один з методів виховання учнів початкових класів. Початкова школа. 2016. № 10.С. 52-53.

5. Кукушин В. Ігрові технології на уроках. Відкритий урок. 2006. № 11/12. С. 3-9.

6. Любченко О. Дидактичні ігри в навчальновиховному процесі. Методичний порадник. 2015. № 8 . C. 14-17.
7. Мицик О. Гра як метод навчання іншомовного спілкування учнів початкової школи. Англійська мова та література. 2013. № 22-23 (392-393). С. 40-49.

8. Пищик О. Ділова гра як інноваційний метод педагогічної діяльності. Педагогічна майстерня. 2013. №6. C. 2-5.

9. Платов В.Я. Ділові ігри: розробка, організація та проведення: Підручник. Київ: 1991.156 с.

10. Савченко О.Я. Дидактика початкової школи : підруч. для студ. пед. факульт. Київ : Генеза, 2002. 368 с.

\section{REFERENCES}

1. Artemova, L.V. (1990). Vchysia hraiuchys [Learn by playing]. Kyiv, p.170. [in Ukrainian].

2. Bulyhina, O. (2009). Ihrovi tekhnolohii: shliakhy zabezpechennia umov dlia intelektualnoho, sotsialnoho, moralnoho rozvytku molodshykh shkoliariv [ Game technologies: ways to provide conditions for intellectual, social, moral development of junior schoolchildren]. Primary education and upbringing. No. 19-21. pp. 2-14. [in Ukrainian].

3. Derzhavnyi standart pochatkovoi zahalnoi osvity (Ministerstvo osvity i nauky Ukrainy) (2021). [State standard of primary general education (Ministry of Education and Science of Ukraine)]. Available at: https:// zakon.rada.gov.ua/laws/show/688-2019-\%D0\%BF\#Text (Accessed 24 July 2021). [in Ukrainian].

4. Dzhelialova, I. (2016). Hra yak odyn z metodiv vykhovannia uchniv pochatkovykh klasiv [Game as one of the methods of educating primary school students]. Elementary School. No. 10. pp. 52-53. [in Ukrainian].

5. Kukushyn, V. (2006). Ihrovi tekhnolohii na urokakh [Game technologies in lessons]. Open lesson. No. 11/12. pp. 3-9. [in Ukrainian].

6. Liubchenko, O. (2015). Dydaktychni ihry v navchalno-vykhovnomu protsesi [Didactic games in the educational process]. Methodical guide. No. 8. pp. 14 17. [in Ukrainian].

7. Mytsyk, O. (2013). Hra yak metod navchannia inshomovnoho spilkuvannia uchniv pochatkovoi shkoly [Game as a method of teaching foreign language communication to primary school students]. English language and literature. No. 22-23 (392-393). pp. 40-49. [in Ukrainian].

8. Pyshchyk, O. (2013). Dilova hra yak innovatsiinyi metod pedahohichnoi diialnosti [Business game as an innovative method of pedagogical activity]. Pedagogical workshop. No. 6. pp. 2-5. [in Ukrainian].

9.Platov, V.Ia. (1991). Dilovi ihry: rozrobka, orhanizatsiia ta provedennia [Business games: development, organization and conduct]. Textbook. Kyiv, 156 p. [in Ukrainian].

10. Savchenko, O.Ia. (2002). Dydaktyka pochatkovoi shkoly : pidruch. [Primary school didactics: textbook]. Kyiv, 368 p. [in Ukrainian].

Стаття надійшла до редакції 16.07.2021 